\title{
Management of the Elderly Inflammatory Bowel Disease Patient
}

\author{
Petr Hruz ${ }^{a}$ Pascal Juillerat ${ }^{b}$ Gerd-Achim Kullak-Ublick ${ }^{c}$ Alain M. Schoepfer ${ }^{d}$ \\ Gerassimos J. Mantzaris ${ }^{\mathrm{e}}$ Gerhard Rogler ${ }^{f}$ on behalf of the Swiss IBDnet, \\ an official working group of the Swiss Society of Gastroenterology
}

${ }^{a}$ Department of Gastroenterology and Hepatology, Clarunis Basel, Basel, Switzerland; ${ }^{b}$ Department of Gastroenterology and Hepatology, University Clinic for Visceral Surgery and Medicine, University Hospital of Bern, Bern, Switzerland; ' Department of Clinical Pharmacology and Toxicology, University Hospital Zurich, University of Zurich, Zurich, Switzerland; 'Department of Gastroenterology and Hepatology, Centre Hospitalier Universitaire Vaudois and University of Lausanne, Lausanne, Switzerland; ${ }^{\text {DDepartment }}$ of Gastroenterology, "Evangelismos-Ophthalmiatreion Athinon-Polycliniki" Hospitals, Athens, Greece; ${ }^{f}$ Department of Gastroenterology and Hepatology, University Hospital Zurich, University of Zurich, Zurich, Switzerland

\section{Keywords}

Crohn's disease - Ulcerative colitis - Elderly · Management

\begin{abstract}
Inflammatory bowel disease (IBD) is increasingly diagnosed among elderly persons (older than 60 years). Epidemiological studies show that late-onset IBD is characterized by predominance of colonic disease, milder disease course, and less frequent occurrence of extraintestinal manifestations. However, due to comorbidities, polypharmacy and reduced resistance to severe disease course elderly patients have an increased risk of mortality. Drug treatment generally follows the same algorithms as in the younger IBD patients. This is challenging for the treating physician as this population is usually underrepresented in clinical trials and treatment outcomes as well as safety data on the elderly population are scarce. Choice of drugs should consider risk of infections, skin cancer, lymphoma, and metabolic as well as cardiovascular side effects. Considering comorbidities, surgical interventions such as colectomy with ileo-anal pouch anastomosis for refractory ulcerative colitis can be performed safely provided that the anal sphincter function is adequately
\end{abstract}

maintained. Special attention should be given in this age group to general health issues, including nutrition, vaccination, bone, muscle, and mental health as well as colorectal and skin cancer screening.

(c) 2020 S. Karger AG, Basel

\section{Introduction}

Crohn's disease (CD) and ulcerative colitis (UC) are both chronic inflammatory conditions of the gut related to a combination of genetic and environmental factors that impact on normal host - microbe interactions [1]. More and more importance is attributed to age-related immunosenescence which is associated with a relative systemic immunodeficiency compared with younger people, with declines in functionality of both innate and adaptive immunity $[2,3]$. Immune disturbances of the luminal mucosal immune system with ageing might result in an inability to mount protective immune responses to exposure to new antigens [4]. These antigens are arising from commensal microorganisms, dietary products, and occasional pathogens, but these factors explain only a small karger@karger.com

www.karger.com/dig

(C) 2020 S. Karger AG, Base

Karger'"
Petr Hruz

Department of Gastroenterology and Hepatology

Clarunis Basel, Petersgraben 4

CH-4031 Basel (Switzerland)

E-Mail petr.hruz@ clarunis.ch 
fraction of disease risk. Another factor may be endothelial dysfunction that is considered an initial step in the pathogenesis of atherosclerosis in the general population. In inflammatory bowel disease (IBD), the inflammatory process leads to functional and structural changes in the vascular endothelium with an increase of leukocyte adhesiveness and leukocyte diapedesis and an increased vascular smooth muscle tone and procoagulant activity is observed $[5,6]$. In younger IBD patients, genetic factors are probably of greater importance than in older patients where cumulative exposure to environmental factors (exposome) may have a more prominent role to drive disease development. So just 7\% of CD subjects over the age of 60 had a family history versus $16 \%$ of patients with disease onset before 16 years of age [7]. The term "exposome" was proposed to reflect a life-course of environmental influences beginning in utero and proceeding right through childhood to adulthood $[8,9]$. Several factors such as diet, food additives (dietary emulsifiers), nanoparticles, air and water pollution, exposure to smoking, drugs (e.g., antibiotics and nonsteroidal anti-inflammatory drugs), infections, hypoxia, and others have been identified as environmental contributors in this concept [10].

\section{The Role of the Microbiota in Older IBD Patients}

Intestinal dysbiosis is associated with several chronic conditions, including inflammatory diseases. IBD patients characteristically show a reduced biodiversity and altered composition of the intestinal microbiota with quantitatively increased abundance in bacteria which include Enterobacteriaceae, Pasteurellacaea, Veillonellaceae, and Fusobacteriaceae and decreased abundance in Erysipelotrichales, Bacteroidales, and Clostridiales which correlates strongly with disease status $[11,12]$. The microbiota of older people display greater inter-individual variation than that of younger adults [13]. Analysis of microbiota of elderly subjects with different residence locations (community, day-hospital, rehabilitation, or in long-term residential care) indicated that gut microbiota correlate to diet and health condition upon ageing [14]. Interestingly, the individual microbiota of people in long-stay care was significantly less diverse than that of community dwellers and loss of community-associated microbiota correlated with increased frailty. One of the potential factors where the microbiome is altered as a consequence of exposure to an environmental factor is use of antibiotics $[15,16]$. Microbiome comparison between $\mathrm{CD}$ patients with and without antibiotic exposure indicates that antibiotic use amplifies the microbial dysbiosis associated with CD [11]. Modulating intestinal microbial composition therefore may represent a promising strategy for treatment of patients with IBD. Fecal microbiota transplantation and probiotics have been explored as promising candidates to reestablish microbial balance in IBD [17]. These microbial-based therapies have demonstrated the ability to reduce both the dysbiotic environment and production of inflammatory mediators, thus inducing remission, especially in a part of UC patients [18-20]. Whether the changes of the microbiota seen in the elderly play a specific role for IBD disease course remains to be elucidated. Systematic analyses in cohorts of older patients and comparisons with younger cohorts have not been performed. As it has been postulated that the composition of the microbiota in the elderly may contribute to changes in the intestinal mucosal innate immune system and immune reactions this analysis would indeed be important.

\section{Epidemiology}

Epidemiological data are often reported together for both forms of IBD, UC, and CD with most of IBD patients being diagnosed at young age. Several studies have shown a bimodal age distribution with a peak incidence in the second to fourth decade and a second smaller peak in incidence in the sixth to eighth decade $[21,22]$. Due to worldwide rising incidence of IBD and as a consequence of the ageing population an increase in the incidence and prevalence rate of IBD in the elderly is not surprising [23]. Factors such as urbanization, improved disease awareness, or improved diagnostics have been attributed to increase the number of elderly individuals living with IBD. Estimations for the incidence rates in UC in the elderly are ranging between 3 and 17 per 100,000 and in CD between 3 and 6 per $100,000[7,24,25]$. A recent nationwide population-based study from Sweden reported an incidence rate of 35 per 100,000 person years for IBD patients $>60$ years or older with a clearly higher rate for UC compared to CD [26]. Several population-based studies suggest that late-onset IBD has a milder clinical course with less frequent use of immunomodulators as well as biologics, a lower rate of extraintestinal manifestations, and similar surgery rates when compared with younger IBD patients [7, 24-26]. However, especially correlating the use of drug treatments with the clinical course may be misleading as use of different drug classes may be influenced by comorbidities and polypharmacy in the elderly population and some drug classes may be avoided by the prescribing physicians for safety reasons. 
As shown in the population-based study from Sweden elderly patients used fewer biologics and immunomodulators but had a higher use of systemic corticosteroids compared with pediatric and adult-onset IBD [26].

\section{Clinical Presentation}

The clinical presentation of patients with CD and UC differs between older and younger patients. Older-onset of $\mathrm{CD}$ is more frequently associated with isolated colonic inflammation and perianal fistulas and less small bowel and upper gastrointestinal disease [7, 25]. Inflammatory phenotype is more often observed in elderly CD patients than stricturing or penetrating disease. Elderly UC patients seem to have less isolated proctitis but more left sided and extensive colitis, and the disease location in elderly UC patients tends to remain stable with only a small fraction of patients showing disease extension at followup [7]. A considerable delay in diagnosis of up to 6 years in the elderly compared to 2 years in younger adults has been observed [27]. Overall elderly IBD patients present with more subtle clinical symptoms. Elderly-onset CD subjects report less abdominal pain, systemic symptoms, and diarrhea, while subjects with a diagnosis of UC in older age report less abdominal pain and rectal bleeding [28]. In the differential diagnosis, the evaluation aims to exclude primarily malignancies (cancer and lymphoma) and infectious causes. But several other conditions of gastrointestinal inflammation can occur in the elderly that include diverticulitis, ischemic colitis, microscopic colitis, drug-induced colitis (e.g., nonsteroidal anti-inflammatory drugs), or in case of a personal history of radiation therapy radiation-induced colitis (proctitis) and all these conditions should be excluded [29]. It is important to assess the personal and medical history for preexisting conditions such as cardiovascular diseases, diabetes mellitus, malignancies, functional and cognitive impairments, smoking history, and renal dysfunction which are prevalent comorbidities in elderly and which is crucial for correct assessment of the clinical condition and subsequently initiation of treatment.

\section{Treatment}

General Management and Treatment of Elderly IBD Patients

Management of elderly IBD patients has been insufficiently studied since older adults are underrepresented in clinical trials and no specific treatment algorithms have been developed for this age group. In recent years in many clinical trials, patients older than 65 were systematically excluded. Therefore, currently drug treatment in the elderly follows principles that are established for younger IBD patients. Benefits of the chosen drug treatment should outweigh potential side effects and should consider specific safety issues. This is highly relevant as in a recent Swiss IBD Cohort study addressing safety issues a positive correlation between the number of concomitantly administered IBD drugs and the occurrence of side effects requiring drug cessation was observed [30]. Also in the elderly population, additional factors have to be considered as cardiovascular diseases, hypertension, diabetes mellitus, malignancies, functional and cognitive impairments, smoking history, and renal dysfunction are more prevalent [31]. Physicians should be at greater awareness that these patients may be treated already with different medications as polypharmacy increases the risk of drug-drug interactions and may trigger or worsen concomitant diseases [31]. Age-dependent changes in liver and renal function and age-related body composition (increase of body fat, decrease of lean muscle mass, hypoproteinemia) may impair the pharmacokinetics of medications and have to be considered while prescribing additional therapies in these patients. Specific attention has to be given also to infections in IBD patients on immunosuppressive therapy as they tend to occur more often due to age-related alterations in natural barriers and immunesenescence and are prone to a more serious clinical course [32].

In summary, treatment strategies in elderly IBD patients based on the location and severity of inflammation should implement the following goals: to induce and maintain remission to prevent disease-related complications, to avoid adverse events, and to improve quality of life. In the following sections, the commonly used IBD drug classes are discussed and information about side effects, drug-drug interactions, and specific recommendations is provided in Table 1.

\section{5-Aminosalicylates}

Oral and topical 5-aminosalicylates (5-ASA) are highly effective as induction and maintenance treatment for UC but less effective in CD [33-36]. Interestingly, a recent analysis indicates that mesalazine was the most frequent prescribed drug treatment for the elderly IBD patients and $80 \%$ of CD and $84 \%$ of UC patients have been treated with mesalazine within 10 years of diagnosis $[7,37]$. The high frequency of mesalazine 
Table 1. Common side effects and drug-drug interactions for therapies used in elderly IBD patients

\begin{tabular}{|c|c|c|c|c|}
\hline Drug class & Substance(s) & Side effects & Drug-drug interactions & Precautions and specific recommendations \\
\hline Aminosalicylates & $\begin{array}{l}\text { Mesalazine } \\
\text { (5-ASA) }\end{array}$ & $\begin{array}{l}\text { - Rare }(<0.1 \%) \text { headache, dizziness, } \\
\text { abdominal pain, bloating, diarrhea, } \\
\text { nausea, vomiting, arthralgia, myalgia, } \\
\text { skin rash } \\
\text { - Very rare }(<0.01 \%) \text { : nephrotoxicity, } \\
\text { leukopenia, hepatitis }\end{array}$ & $\begin{array}{l}\text { - In combination with thiopurines 5-ASA } \\
\text { increases the risk of leukopenia } \\
\text { - 5-ASA increases the anticoagulant activity } \\
\text { of warfarin }\end{array}$ & $\begin{array}{l}\text { Monitoring of laboratory parameters } \\
\text { (blood count and renal function) }\end{array}$ \\
\hline Corticosteroids & $\begin{array}{l}\text { Prednisone } \\
\text { Budesonide* }^{*}\end{array}$ & $\begin{array}{l}\text { - General occurrence of metabolic } \\
\text { and endocrine side effects including } \\
\text { diabetes, hypertension, adrenal } \\
\text { suppression, gynaecomastia } \\
\text { - Increased risk for osteoporosis, } \\
\text { impaired wound healing, myopathy, } \\
\text { aseptic necrosis of bones, } \\
\text { gastrointestinal bleeding or } \\
\text { perforation, infections, glaucoma, } \\
\text { depression, delirium, psychosis }\end{array}$ & $\begin{array}{l}\text { - Concomitant use of CYP3A4 } \\
\text { inhibitors increase concentrations } \\
\text { and effect of steroids } \\
\text { - In combination with NSAIDS } \\
\text { increased risk for peptic ulcer } \\
\text { - Steroids modulate the activity of } \\
\text { anticoagulant drugs, reduce the effects } \\
\text { of antidiabetic agents, increase the } \\
\text { hypokalemic effects of diuretics } \\
\text { - Antiepileptic drugs (phenobarbital, } \\
\text { phenytoin) reduce the efficacy of steroids }\end{array}$ & $\begin{array}{l}\text { - Pronounced adverse events in elderly } \\
\text { patients; limit prescription to short } \\
\text { applications (<3 months) } \\
\text { - Clinical and laboratory monitoring: } \\
\text { blood pressure, diabetes, eyes, } \\
\text { coagulation } \\
\text { - Osteoporosis prevention and } \\
\text { screening }\end{array}$ \\
\hline Thiopurines & $\begin{array}{l}\text { Azathioprine } \\
\text { 6-Mercaptopurine }\end{array}$ & $\begin{array}{l}\text { - Nausea, vomiting }(5-10 \%) \\
\text { - Flu-like symptoms }(5 \%) \\
\text { - Leukopenia }(<10 \%) \text {, agranulocytosis } \\
\quad(<0.5 \%) \\
\text { - Pancreatitis }(5-15 \%) \text { hepatotoxicity } \\
\quad(10 \%) \\
\text { - Skin rash }(<5 \%)\end{array}$ & $\begin{array}{l}\text { - Increased risk of myelotoxicity in } \\
\text { combination with allopurinol } \\
\text { - Increased risk of leukopenia in } \\
\text { combination with 5-ASA }\end{array}$ & $\begin{array}{l}\text { - Monitoring of laboratory parameters } \\
\text { (blood count, liver function, lipase) } \\
\text { - TPMT activity or check drug level } \\
\text { of metabolites }\end{array}$ \\
\hline $\begin{array}{l}\text { Folate } \\
\text { antagonist }\end{array}$ & $\begin{array}{l}\text { Methotrexate } \\
\text { (indication for } \\
\text { low-dose } \\
\text { application) }\end{array}$ & $\begin{array}{l}\text { - Abdominal discomfort, nausea, } \\
\text { vomiting, diarrhea }(>10 \%) \text {, stomatitis } \\
\quad(1-10 \%) \\
\text { - Headache, fatigue }(<10 \%) \text {, dizziness } \\
\quad(<1 \%) \\
\text { - Hair loss }(<1 \%) \text {, skin rash }(<10 \%) \\
\text { - Increased liver enzymes }(>10 \%), \\
\text { chronic use with risk for liver cirrhosis } \\
\text { - Interstitial pneumonitis }(1-10 \%) \\
\text { - Myalgia, arthralgia }(<1 \%) \\
\text { - Anemia, leukopenia, thrombocytopenia } \\
\text { ( }<10 \%) \text {, agranulocytosis }(<0.01 \%)\end{array}$ & $\begin{array}{l}\text { - Various drug-drug interactions due to } \\
\text { alterations in plasma protein binding, } \\
\text { renal clearance, and intestinal resorption } \\
\text { - Increased methotrexate concentration } \\
\text { in combination with 5-ASA, NSAIDs, } \\
\text { antibiotics (penicillin, tetracyclines, } \\
\text { sulfonamides) } \\
\text { - Methotrexate decreases theophylline } \\
\text { clearance, increases the effect of } \\
\text { coumarin derivatives }\end{array}$ & $\begin{array}{l}\text { - Monitoring of laboratory parameters } \\
\text { (blood count and liver enzymes) } \\
\text { - Supplementation with folic acid } \\
5 \mathrm{mg} 24 \text { h after methotrexate } \\
\text { - Specific attention to liver disease } \\
\text { (hepatotoxicity) and renal insufficiency }\end{array}$ \\
\hline $\begin{array}{l}\text { Calcineurin } \\
\text { inhibitor }\end{array}$ & Cyclosporine & $\begin{array}{l}\text { - Headache, migraine }(15 \%) \text {, tremor } \\
\text { ( } 10-20 \%) \text {, paresthesia }(<10 \%) \\
\text { - Abdominal discomfort, nausea, } \\
\text { vomiting, gingival hyperplasia }(>10 \%) \\
\text { - Renal insufficiency }(10-50 \%), \\
\text { hypertension }(15-40 \%) \text {, increase } \\
\text { of liver enzymes }(<10 \%) \\
\text { - Leukopenia }(5-10 \%) \text {, hyperlipidemia } \\
\quad(>10 \%) \\
\text { - Hypertrichosis }(>10 \%) \text {, acne, rash } \\
\quad(1-10 \%) \\
\text { - Increased risk for infections }\end{array}$ & $\begin{array}{l}\text { - Drug interactions can occur with drugs } \\
\text { that are substrates of CYP3A4 and } \\
\text { P-glykoprotein } \\
\text { - Avoid concomitant use of drugs with } \\
\text { nephrotoxic properties }\end{array}$ & $\begin{array}{l}\text { - Use not recommended in elderly } \\
\text { patients } \\
\text { - Check for hypertension } \\
\text { - Avoid grape fruit juice } \\
\text { - Regular monitoring for renal function, } \\
\text { cyclosporine drug level }\end{array}$ \\
\hline $\begin{array}{l}\text { TNFa } \\
\text { blockers }\end{array}$ & $\begin{array}{l}\text { Adalimumab } \\
\text { Golimumab } \\
\text { Certolizumab }\end{array}$ & $\begin{array}{l}\text { - Headache, fatigue, dizziness, fever } \\
\text { ( } 1-10 \%) \\
\text { - Abdominal discomfort, nausea } \\
\text { ( } 1-10 \%) \\
\text { - Increased risk of infections }(1-10 \%) \text {, } \\
\text { including opportunistic infections } \\
(<0.1 \%) \\
\text { - Infusion reactions, allergic reactions } \\
\text { ( } 5-10 \%) \\
\text { - Skin rash }(5-10 \%) \text {, various skin } \\
\text { diseases }(1-5 \%), \text { TNFa blocker } \\
\text { induced psoriasis }(<1 \%) \\
\text { - Lupus-like syndrome }(<1 \%), \\
\text { anaphylaxis }(<1 \%) \\
\text { - In general better side effect profile } \\
\text { of subcutaneous application } \\
\text { formulations } \\
\text { - Local irritation at injection site }\end{array}$ & $\begin{array}{l}\text { Concomitant use of immunomodulators } \\
\text { may suppress the formation of antidrug } \\
\text { antibodies }\end{array}$ & $\begin{array}{l}\text { - Screening before treatment }{ }^{\mathrm{a}} \\
\text { - Monitoring of laboratory parameters } \\
\text { - Contraindicated in cardiac } \\
\text { insufficiency (NYHA III-IV) } \\
\text { - Use with caution in patients with chronic } \\
\text { liver disease, neurological pathology, or } \\
\text { history of malignancy, especially lym- } \\
\text { phoma }\end{array}$ \\
\hline
\end{tabular}


Table 1 (continued)

\begin{tabular}{|c|c|c|c|c|}
\hline Drug class & Substance(s) & Side effects & Drug-drug interactions & Precautions and specific recommendations \\
\hline $\begin{array}{l}\text { Integrin } \\
\text { inhibitors }\end{array}$ & Vedolizumab & $\begin{array}{l}\text { - Nasopharyngitis }(10 \%) \text { upper } \\
\text { respiratory and intestinal infections } \\
\\
(1-10 \%) \\
\text { - Headache }(10 \%) \text {, arthralgia }(>10 \%) \\
\text { - Abdominal discomfort, nausea }(1-10 \%) \\
\text { - Allergic infusion reactions }(<1 \%), \\
\text { fever }(1-10 \%)\end{array}$ & $\begin{array}{l}\text { Pharmacokinetic studies with thiopurines } \\
\text { or methotrexate do not indicate relevant } \\
\text { changes in pharmacokinetics of } \\
\text { vedolizumab }\end{array}$ & $\begin{array}{l}\text { - Screening before treatment }{ }^{\mathrm{a}} \\
\text { - Monitoring of laboratory parameters } \\
\text { - No signal for PML }\end{array}$ \\
\hline Anti-IL-12/23 Ab & Ustekinumab & $\begin{array}{l}\text { - Headache, fatigue, dizziness }(5-10 \%) \\
\text { - Nasopharyngitis }(5-10 \%) \text {, lower } \\
\text { respiratory tract infections }(<1 \%), \\
\text { cellulitis }(<1 \%) \\
\text { - Abdominal discomfort, vomiting, } \\
\text { nausea, diarrhea }(<10 \%) \\
\text { - Arthralgia }(5-10 \%) \text {, urticaria }(<1 \%) \\
\text { - Local irritation at injection site }(1-10 \%)\end{array}$ & $\begin{array}{l}\text { Attention to combination therapies with } \\
\text { other immunosuppressive drugs due to } \\
\text { potentiation of immunosuppression } \\
\text { and risk for severe infections }\end{array}$ & $\begin{array}{l}\text { - Screening before treatment }{ }^{\mathrm{a}} \\
\text { - Monitoring of laboratory parameters } \\
\text { - Rare observation: reversible PRES }\end{array}$ \\
\hline $\begin{array}{l}\text { Small } \\
\text { molecule }\end{array}$ & Tofacitinib & $\begin{array}{l}\text { - Headache, fatigue }(<10 \%) \\
\text { - Upper/lower respiratory tract and } \\
\text { urinary tract infections }(1-10 \%) \\
\text { - Herpes zoster infection }(5-10 \%) \\
\text { - Abdominal discomfort, diarrhea, } \\
\text { nausea }(<10 \%) \\
\text { - Hypertension }(<10 \%) \text {, hyperlipidemia } \\
\quad(<1 \%) \\
\text { - Skin rash }(<10 \%) \text {, arthralgia }(<10 \%)\end{array}$ & $\begin{array}{l}\text { Drug interactions can occur with } \\
\text { drugs that are substrates of CYP3A4 } \\
\text { and CYP2C19 }\end{array}$ & $\begin{array}{l}\text { - Laboratory monitoring (blood count, } \\
\text { lipid status, creatinine kinase) } \\
\text { - Check VZV IgG, if positive, } \\
\text { consider Shingrix vaccination } \\
\text { - Specific precautions in patients with } \\
\text { increased risk for pulmonary embolism } \\
\text { especially tofacitinib } 10 \mathrm{mg} \text { bid }\end{array}$ \\
\hline
\end{tabular}

\footnotetext{
* Less systemic side effects due to high first-pass effect in the liver.

a Screening for active or latent tuberculosis including chest X-ray, Hepatitis B (HBs ag; anti-HBc ab), HIV serology, blood count, liver function; vaccination with live vaccines prior to initiation if indicated.

IBD, inflammatory bowel disease; 5-ASA, 5-aminosalicylates; TPMT, thiopurine methyltransferase; PML, progressive multifocal leukoencephalopathy; PRES, posterior reversible encephalopathy syndrome.
}

use in older adults might be explained by its excellent tolerability and the limited number of alternatives, especially for mild to moderate disease course. In patients with ulcerative proctitis or left-sided colitis, a combination of oral and topical mesalazine is more effective than either alone [38]. For better adherence rates, oncedaily dosing is recommended as compliance is an important issue in the elderly. Problems with self-administration of topical agents especially with suppositories, enemas, and foam may limit usage in some elderly patients due to impaired mobility and incontinence [35, $39,40]$.

5-ASA are generally considered safe and efficacious, the most common adverse reactions include nausea and vomiting, headache, abdominal pain, and rash [38]. Nephrotoxicity is a rare adverse event in patients on 5-ASA treatment and specific attention should be given to patients with underlying kidney disease. Renal function should be checked before and during therapy. Leukopenia can occur when 5-ASA agents are used in combination with thiopurines, due to an increase in 6-thioguanine levels, the active metabolite of azathioprine, and 6-mercaptopurine (6-MMP) [41, 42].

\section{Steroids}

As fast-acting drugs corticosteroids are often used as induction agents in both $\mathrm{UC}$ and $\mathrm{CD}$ for rapid control of symptoms. A significant use of corticosteroids is reported in elderly IBD patients $[7,43,44]$, and a recent analysis demonstrates that a proportion of $20-40 \%$ of IBD patients are treated with corticosteroids during the first 5 years following IBD diagnosis [26]. Therefore, metabolic (i.e., diabetes mellitus, dyslipidemia, weight gain, lipodystrophy) and cardiovascular (i.e., hypertension, cardiovascular events) adverse events have to be considered specifically in this patient group and repetitive or prolonged courses of corticosteroids should be avoided [45]. Prolonged use of steroid-based therapies may worsen different clinical conditions such as preexisting diabetes mellitus, hypertension, infections (e.g., pneumonia), eye lens cataract, or may cause mental state alterations [31, 46]. Attention has to be given also to corticosteroid-induced osteoporosis and the risk of bone fractures. In Swiss IBD patients, corticosteroids and age were the most relevant risk factors for decreased bone mineral density [47]. The risk of gastrointestinal bleeding is increased in elderly patients especially when corticosteroids are given concomi- 
tantly with nonsteroidal anti-inflammatory drugs. This suggests that screening for risk factors for upper gastrointestinal bleeding should be routinely done and subsequent prophylactic PPI treatment installed [48]. Due to the high first-pass metabolism in the liver, budesonide or modified release formulations of budesonide have fewer systemic effects compared with prednisone and should be considered in mildly-to-moderately active disease in elderly IBD patients [49-51]. However, it has to be considered that side effects of topical steroids may be more frequent in the elderly patients.

\section{Immunosuppressive Drugs: Thiopurines,}

Methotrexate, Cyclosporine

Thiopurines are purine antimetabolites that inhibit cell proliferation especially of lymphatic cells and are effective to maintain remission in CD and UC $[38,52]$. No differences in efficacy have been noted with the use of thiopurines in the elderly [53]. However, the use of thiopurines in the elderly needs very careful consideration and monitoring due to potential drug interactions, increased risk of lymphoma, non-melanoma skin cancer, and infection [54]. Dose-dependent adverse events include nausea, vomiting, and dyspepsia and occurrence of leucopenia (in severe cases agranulocytosis) and elevation of transaminases; therefore, regular monitoring with complete blood count and liver function tests is required [55]. Determining the thiopurine methyltransferase activity may reduce the time to therapeutic drug levels and can help to identify patients at risk for myelosuppression and to prevent toxicity [55]. Allopurinol may enhance the myelosuppressive effects of thiopurines by blocking thiopurine methyltransferase activity. Blocking of this enzymatic activity with allopurinol with concomitant reduction of azathioprine (to $25-33 \%$ of normal weight based dose) is used in some patients with increased methylated 6-MMP levels ("hypermethylators") to enhance therapeutic efficacy. Dose-independent adverse event pancreatitis, flu like symptoms, and occurrence of rash can be observed in a minority of patients treated with thiopurines. The risk of lymphoma in IBD patients treated with azathioprine and 6-MMP was found increased especially in the elderly population $[54,56]$. The CESAME cohort indicated that the risk significantly increases above the age of 65 [57]. There does not seem to exist a significant gender difference concerning the distribution of lymphoma except for the hepatosplenic T-cell lymphoma cases which were seen predominantly in younger men and not so relevant in the elderly population [58]. A recent study associated increasing age, especially in older men, with an increased risk of urinary tract cancers in patients with IBD receiving thiopurines [59]. In addition, patients on immunosuppressive medications have a substantially elevated risk of non-melanoma skin cancer [60]. IBD patients using thiopurines seem to have a moderately increased risk for non-melanoma skin cancer which is proportional to therapy duration and which decreases or returns to baseline risk after discontinuing therapy [61]. Younger patients with IBD using thiopurines seem to be at greater risk of developing non-melanoma skin cancer, which suggests early implementation of skin cancer screening recommendations and strict application of sun protection. In summary, there are ongoing discussions whether use of thiopurines in the elderly population is safe. In general, it is recommended to perform a very careful risk/benefit analysis given the increased cancer risk in the elderly population and thiopurines should be used with caution in this age group.

The use of methotrexate monotherapy in patients with IBD is of controversial discussion. Methotrexate has not been studied exclusively in elderly IBD patients, but retrospective cohort data indicate limited use in the elderly with similar outcomes compared to young patients [62]. In the rheumatology literature in older patients with rheumatoid arthritis (RA), similar responsiveness of methotrexate to that in younger patients was observed [63]. For patients with CD induction and maintenance of remission/clinical response with 10-25 mg methotrexate subcutaneous weekly was shown $[64,65]$. The effect seems to be more pronounced in combination with anti-TNF therapy [66]. For patients with UC methotrexate was not found to be better than placebo in the induction, maintenance of remission, or preventing relapses of UC in patients who achieved steroid-free response $[67,68]$. Attention should be given to symptoms of general malaise, gastrointestinal complaints, and asymptomatic increase of liver enzymes [62, 69]. Use of folic acid supplementation is mandatory in patients treated with methotrexate.

Cyclosporine is used for rescue therapy in severe UC patients. It is not recommended in elderly IBD patients given the risk profile for comorbidities such as hypertension and renal disease in this patient group $[54,70]$. If cyclosporine is used, monitoring of the renal function should be assured.

\section{Biologics: TNF $\alpha$ Blockers, Anti-Integrins, and Anti} IL-12/23

Anti-TNF agents are used in moderate to severe CD and UC and are effective in inducing clinical and endoscopic remission, decreasing rates of hospitalization and 
surgery. Although some data suggest a lower rate of shortterm clinical response in elderly IBD patients to antiTNFs there is no evidence that the efficacy of medical treatment in elderly IBD patients differs from that in younger adult patients $[54,71,72]$. In patients $>65$ years similar clinical remission rates of $59 \%$ in UC and $65 \%$ in CD after approximately 2 years of treatment on infliximab or adalimumab compared to younger patients was observed [73]. Long-term clinical response to anti-TNF agents seems to be similar between those initiating the drug before and after age 65 [71]. But patients older than age 60 at the time of initiation of anti-TNF therapy are at higher risk for discontinuation of therapy probably due to side effects such as increased vulnerability to infectious complications [74]. This goes in line with the finding that older corticosteroid-responsive patients were less likely to be treated with an anti-TNF than younger patients [72]. There are no specific data addressing the effectiveness of combination therapy, particularly anti TNFa treatment in combination with thiopurines in the elderly.

The most prominent adverse events due to anti TNFa therapy include infusion reactions, abdominal discomfort, infections (including bacterial, viral, fungal, and opportunistic infections) as well as rare occurrence of autoimmune, dermatological disorders, cardiac, and neurological conditions [75]. Cottone et al. [73] reported a 12\% risk of serious infection in the elderly on anti-TNF agents, including pneumonia and sepsis. The increased use of TNFa in clinical practice raised concerns about a possible association with cancer. Data from registries regarding patients with RA showed that the overall incidence of cancer is similar to that observed in the general population $[76,77]$. However, anti-TNFa treatment in combination with immunomodulators is associated with an increased risk of developing non-Hodgkin lymphoma in adult CD patients $[78,79]$. As main risk factors for developing lymphoproliferative disorder older age, male sex, and longer duration of IBD were identified $[57,80]$. Also, anti-TNF therapy has been associated in IBD patients with an increased risk of melanoma (OR 1.88; 95\% CI 1.08-3.29), which was not confirmed in a large nested Canadian case-control study $[81,82]$. The risk to develop recurrent malignancy on TNF- $\alpha$ inhibitor therapy in patients with previous malignancies cannot be definitively answered as studies have shown contradictory findings [83]. In the British biologics register for RA patients, treatment with $\mathrm{TNF}$ a inhibitor seems not to increase recurrent malignancy as the recurrent malignant incidence was not higher than the control group of RA patients with prior malignancy not treated with biologics [84].

Elderly IBD Patient
In summary, anti-TNF- $\alpha$ agents are contraindicated in patients with cardiac insufficiency and must be used with caution in patients with chronic liver disease, neurological pathology, or history of malignancy, especially lymphoma in patients on combination with immunomodulators [85].

Newer biological therapies include the anti-integrin blocker vedolizumab and the monoclonal antibody ustekinumab blocking the IL-12/23 axis. The gut-specific integrin blocker vedolizumab has been shown to effectively induce remission and to maintain remission in patients moderate to severe CD and UC $[86,87]$. In a small study, the efficacy and safety of VDZ in elderly patients (>60 years old) with UC and CD were shown with clinical remission rate of $41 \%$ at week 52 [88]. In a pooled post hoc analysis, vedolizumab shows a favorable safety profile with low incidence rates of serious infections, infusionrelated reactions, and malignancies over an extended treatment period. No increased risk of any infection or serious infection was associated with vedolizumab exposure [89]. Risk factors associated with serious infection for vedolizumab treated patients with CD were younger age, concurrent corticosteroids, and opiate use. No cases of progressive multifocal leukoencephalopathy related to the JC virus reactivation were reported as it was a concern during the use of its nonselective anti-integrin predecessor natalizumab.

Similarly, ustekinumab that effectively induces and maintains remission in patients with moderate to severe CD seems to offer a favorable infectious safety profile. Randomized clinical trials demonstrated so far no increased infection frequency compared to placebo [90].

\section{Small Molecules: Tofacitinib}

Tofacitinib, an oral, small-molecule Janus kinase inhibitor, was shown to be more effective as induction and maintenance therapy than placebo in moderately to severely active UC [91]. In a safety analysis of patients with moderate to severe UC treated with tofacitinib, additional serious infectious risk was observed, especially a dose relationship with herpes zoster infection [92]. Experience from patients with RA receiving tofacitinib demonstrates that in most cases (93\%) herpes zoster was classified as nonserious, and the majority of patients (94\%) had involvement of only 1 dermatome [93]. Shingrix a new herpes zoster subunit vaccine containing recombinant varicella-zoster virus glycoprotein $\mathrm{E}$ was found to reduce the risks of herpes zoster and postherpetic neuralgia among adults 70 years of age or older [94]. Herpes zoster-related complications in immunocompetent adults were found 
to be reduced by approximately $90 \%$ in adult $\geq 70$ years [95]. Although Shingrix has not yet been tested in immunosuppressed individuals this inactivated recombinant herpes zoster vaccination may become a recommended vaccine before starting tofacitinib.

\section{Surgery}

The indications for surgery are not different between elderly and younger adult patients in both CD and UC. Elderly UC patients were less likely to undergo surgery compared to younger UC patients and have lower rates of total colectomy as well as segmental colectomy [96-99]. In $\mathrm{CD}$ patients, the necessity for surgery appears to be lower with a higher age at the onset of disease $[100,101]$. In severe UC, early surgery has been recommended for elderly patients in order to reduce complications [102]. In UC patients requiring pouch surgery, the surgical approach is not different from younger adult patients and a favorable functional outcome is observed when the patient had a good anal sphincter function documented preoperatively $[103,104]$. However, in case of decreased anal sphincter function, the option of permanent ileostomy instead of ileal anal pouch should be discussed in elderly patients [54]. Overall, elderly IBD patients were found to have a longer postoperative stay and a higher in-hospital mortality rate [105]. Age is independently associated with postoperative morbidity and mortality with preoperative transfusion, emergency operation, and weight loss predicting morbidity for those 80 years of age and older [106]. The rate of major postoperative complications and death among elderly patients has improved in the last decades, which are probably due to availability of more effective IBD medical management, higher emphasis on improving preoperative nutritional status, early mobilization, and/or an increased tendency to perform surgery earlier in the course of disease $[107,108]$.

\section{General Considerations and Recommendations for the Management of Elderly Patients (Table 2)}

\section{Nutrition}

Malnutrition is being observed in IBD due to any combination of inadequate dietary intake associated with feeling unwell, altered nutritional requirements, and/or impairment of nutrient absorption [109]. Malnutrition has been reported in patients with IBD with a prevalence rate of $14 \%$ for patients with CD and 5.7\% with UC and with clearly increased frequencies for hospitalized patients $[110,111]$. Decreased food intake, nutrient malab- sorption, increased intestinal loss, increased energy expenditure, as well as drug interactions may contribute to protein-calorie malnutrition and can be in consequence a considerable risk factor for infectious and other disease-specific complications. Localization, extension of inflammation, disease activity, as well as resection of bowel are some crucial risk factors for deficiencies of macronutrients and of specific micronutrients such as trace elements as well as vitamins and should be monitored when suspected and supplemented if deficiency is observed.

\section{Osteoporosis}

Risk of osteoporosis and osteoporotic fractures is increased in all IBD patients. Besides age-related bone loss elderly IBD patients are at increased risk of osteoporosis and related fractures due to malnutrition, vitamin $\mathrm{D}$ deficiency, corticosteroid treatment, and reduced physical activity [47]. Preventive measures such as supplementation with vitamin $\mathrm{D} /$ calcium, adequate treatment of the underlying disease, and monitoring with osteodensitometry are required.

\section{Infections}

Due to the modification of the immune system in IBD patients, infectious complications - both common and opportunistic - have to be considered during therapy with immunomodulators or biologics. Compared to the non-IBD population, IBD patients are at increased risk of infectious complications including influenza, pneumonia, herpes zoster, Clostridium difficile infection, CMV colitis, and others [112-114]. Opportunistic infections are associated with anti-TNFs, and the risk of opportunistic infection increases with age with patients over 50 years carrying a 3 times increased risk [115]. Severe infections that require admission to the intensive care unit, multiple organ dysfunction, or which fulfill systemic inflammatory response criteria are associated with increased morbidity and mortality. In patients with viral illness experiencing either a severe primary infection or reactivation, biological therapy should be interrupted until appropriate therapy is instituted and clinical improvement is observed. With mild infections biological treatment can be continued [116]. Therefore, assessing an individual patient's risk of therapeutic complications is the first step to improving safety with biologic agents. Treatment guidelines recommend that patients be tested for tuberculosis, hepatitis B, HIV and when appropriate, vaccinations should be given before initiation of biologicals or immunosuppressive treatment [85]. 
Table 2. Recommendations for the management of elderly IBD patients

General considerations

- Assess symptom severity, physical exam, laboratory evaluations, and if indicated endoscopic evaluation

- Choose IBD therapy according individualized goals of care

- Check for concomitant medication regularly

- Consider comorbidities, potential interactions, side effects of treatment

- Monitor for potential drug-drug interactions, check for adherence

- Address smoking cessation (beneficial also for elderly patients)

- Communicate with primary care physician and other specialists

\section{Monitoring}

- Regular office visits

- Be aware of adverse effects to therapy, especially infections

- Laboratory testing (blood count, albumin, renal function, CRP)

- Include check for vitamins (vitamin b12, folic acid, vitamin d), trace elements, and iron status (if indicated) at regular intervals

- Bone densitometry (in patients with long and/or severe inflammation and/or steroid usage or additional risk factors)

- If appropriate calcium and vitamin D supplementation

- Screening for depression or sleep disturbances

- If appropriate ophtalmological exam

- Be aware of thrombotic risk or complications in elderly IBD patients

Nutrition and physical activity

- Nutritional optimization, consider dietary counseling if appropriate

- Documentation of weight at regular intervals

- Promote the importance of physical activity

Cancer screening

- Regular colonoscopy screening every 10 years, starting at the age of 50. Consider frequent screening in high-risk individuals

(family history of CRC, severe and extensive colitis, past dysplasia, or primary sclerosing cholangitis)

- Elderly-onset IBD patients might be at higher risk for CRC, screening starting 1-2 years after diagnosis and should be balanced with disease severity, comorbidities, and life expectancy

- In individuals on immunosuppressive medication skin inspection by dermatologist yearly

- In women on immunosuppressive therapy annual cervical cancer screening should be implemented

Vaccinations

- Follow guidelines for elderly individuals (Table 3)

- Avoid vaccinations with live vaccines in the immunosuppressed patient

IBD, inflammatory bowel disease; CRC, colorectal cancer.

\section{Vaccinations}

Immunosenescence makes the elderly more susceptible to infections and in consequence complications of infections. The vaccination guidelines for elderly IBD patients are similar to those for patients without CD or UC. When possible, patients with IBD should receive age-appropriate vaccinations before initiation of immunosuppression [117]. It has to be considered that immunosuppressed patients $>60$ years appear to respond less well to vaccinations. In general, inactivated vaccinations are safe for administration in immunosuppressed individuals. Recommendations for vaccinations in the elderly are presented in Table 3. Specifically, older patients should be given the influenza vaccine annually and the pneumococcal vaccine with a booster revaccination after 5 years [118].
As mentioned before, Shingrix a new herpes zoster subunit vaccine may become a recommended vaccine before starting tofacitinib. However, patients prescribed biologicals and other immunosuppressants should avoid live vaccines, although following the guidelines of the Infectious Disease Society of America live vaccines in those on low dose immunosuppression (prednisone $\leq 20 \mathrm{mg}$ /day, azathioprine $\leq 3.0 \mathrm{mg} / \mathrm{kg} / \mathrm{day}, \mathrm{MMP} \leq 1.5 \mathrm{mg} / \mathrm{kg} /$ day, methotrexate $\leq 0.4 \mathrm{mg} / \mathrm{kg} /$ week) may be considered [119].

\section{Thrombotic Complications}

Spontaneous reporting (pharmacovigilance database VigiBase) of cases of pulmonary embolism and thromboembolism in connection with infliximab should increase the awareness of physicians for such events/complica- 
Table 3. Recommended vaccinations for elderly patients with IBD (adapted from [117])

Guidelines for administration

Inactivated vaccines

Tdap

Hepatitis A

Hepatitis B

dose

Streptococcus pneumoniae

(PCV13 and PPSV 23)

Neisseria meningitidis

2 or 3 doses depending on vaccine in high-risk situations (e.g., splenectomy, travel to endemic areas, military, employee day/preschool care)

\begin{tabular}{|c|c|}
\hline Herpes zoster & 2 doses Shingrix (2-6 months apart) \\
\hline Influenza & $\begin{array}{l}\text { Annual immunization with inactivated tri- or quadrivalent influenza vaccine for patients } 65 \text { and } \\
\text { older; live-attenuated intranasal influenza vaccine contraindicated in immunosuppressed patients }\end{array}$ \\
\hline Tick borne encephalitis & $\begin{array}{l}3 \text { doses }(0,2-4 \text { weeks and } 6-12 \text { months; booster every } 10 \text { years, recommended in } \\
\text { endemic areas with potential exposition to ticks }\end{array}$ \\
\hline \multicolumn{2}{|l|}{ Live vaccines ${ }^{b}$} \\
\hline MMR & 2 doses ( $>28$ days apart) \\
\hline Varicella & If unknown vaccination history or exposure, check VZV IgG titer; if neg 2 doses (4-6 weeks apart) \\
\hline Yellow fever & $\begin{array}{l}\text { Attenuated live vaccine; consult with a travel medicine or infectious disease specialist } \\
\text { prior to travel to tropical areas }\end{array}$ \\
\hline Samonella typhi & $\begin{array}{l}\text { Oral attenuated live vaccine consult with a travel medicine or infectious disease specialist prior to travel to } \\
\text { tropical areas }\end{array}$ \\
\hline \multicolumn{2}{|c|}{$\begin{array}{l}\text { PCV13 one or more years after PPSV23; another dose of PPSV23 should be administered } 5 \text { years after the initial PPSV23 dose. } \\
\text { b Live vaccines are generally contraindicated in immunosuppressed patients; prevaccination washout period of immunosuppressive therapy } \\
\text { should be }>3 \text { months, post-vaccination period before initiating immunosuppressive therapy } 1 \text { month. } \\
\text { IBD, inflammatory bowel disease; Tdap, tetanus, diphteria, pertussis; MMR, measles-mumps rubella. }\end{array}$} \\
\hline
\end{tabular}

A single dose of Tdap recommended at age 11 through 64 years; single dose of $\mathrm{Td}$ (tetanus/diphtheria) every 10 years

Titer check HAV ab; if negative 2 doses at 0 and 6 months

Titer check HBs ab; if negative 3 doses at 1, 1-2, and 4-6 months; optional titer check 1 month after the last dose

Patients at age 65 years or older if at least 5 years have elapsed since their previous PPSV23 dose tions, especially in IBD patients treated with newer drugs. In general, the thrombotic risk in elderly patients is probably underestimated, but thrombotic complications in case of hospitalization represent an increased risk in IBD patients and need prevention. Antithrombotic prophylaxis should therefore be considered in all hospitalized elderly patients with IBD. Treatment of venous thromboembolism in IBD should follow established antithrombotic therapy options taking into account a potentially increased risk of bleeding $[54,120]$.

\section{Cancer Screening}

Thiopurine therapy seems to moderately increase the risk for nonmelanoma skin cancer and the risk of lymphoma in patients with IBD $[54,56,121]$. Both azathioprine and 6-MMP are known photosensitizers that re- duce the minimal erythema dose for UV-A radiation and also play a role in generation of reactive oxygen species $[122,123]$. The increased risk for nonmelanoma skin cancer does not seem to be daily dose-dependent but some studies show a duration-dependent (cumulative dose) trend for increasing risk [124]. Therefore, the importance of sun protective measures and benefits of regular skin cancer screening should be considered.

In a population-based cohort of nearly 30,000 women with IBD reported increased risk for cervical dysplasia in women with IBD and increased risk of cervical cancer [125]. In a retrospective analysis of women under 65 years of age with IBD, $15 \%$ had abnormal Pap smears compared to $5 \%$ among normal patient populations [126]. Therefore, women with IBD on immunosuppressive therapy should undergo annual cervical cancer screening [117]. 


\section{Colorectal Cancer Screening and Tumor Risk in the \\ Elderly}

Colorectal cancer (CRC) screening is recommended in all individuals beyond age 50 and for IBD patients, start of screening colonoscopy is advised 8 years after onset of IBD symptoms [127]. However, several publications suggest that onset of screening in elderly IBD patients should be initiated earlier. In a population-based study, age at diagnosis was a significant risk factor for early-onset CRC cases with $35 \%$ of older patients with both IBD and CRC developed the CRC within 8 years of the IBD diagnosis [128]. A large cohort study found a much shorter interval to diagnosis of flat dysplasia in elderly patients with UC [129]. Other factors that influence the frequency of colonoscopies for surveillance in IBD patients include family history of CRC, severe and extensive colitis, past dysplasia, or primary sclerosing cholangitis [127]. In the elderly, CRC screening should be balanced with disease severity, comorbidities, and life expectancy.

\section{Conclusion}

The medical management of elderly patients with IBD is challenging with respect to diagnosis, drug therapy, and surgical treatment. In recent years, patients older than 65 were systematically excluded from clinical trials and therefore important information about therapy success, outcome, adverse events, and general epidemiological information is often extrapolated from younger IBD populations. It is questionable whether this is ethical. With our ageing population, it needs to be changed urgently to gain better evidence for the treatment of the elderly.

\section{Acknowledgment}

No funding was provided for this manuscript.

\section{Disclosure Statement}

The authors have no conflicts of interest to declare related to this manuscript.

\section{Author Contributions}

All authors conceptualized the extent of the manuscript. P.H. and G.R. drafted the initial manuscript. All authors critically reviewed and approved the final manuscript as submitted.

\section{References}

1 Jostins L, Ripke S, Weersma RK, Duerr RH, McGovern DP, Hui KY, et al.; International IBD Genetics Consortium (IIBDGC). Host-microbe interactions have shaped the genetic architecture of inflammatory bowel disease. Nature. 2012 Nov;491(7422):119-24.

2 Cambier J. Immunosenescence: a problem of lymphopoiesis, homeostasis, microenvironment, and signaling. Immunol Rev. 2005 Jun;205(1):5-6.

3 Linton PJ, Dorshkind K. Age-related changes in lymphocyte development and function. Nat Immunol. 2004 Feb;5(2):133-9.

4 Clegg A, Young J, Iliffe S, Rikkert MO, Rockwood K. Frailty in elderly people. Lancet. 2013 Mar;381(9868):752-62.

5 Cibor D, Domagala-Rodacka R, Rodacki T, Jurczyszyn A, Mach T, Owczarek D. Endothelial dysfunction in inflammatory bowel diseases: Pathogenesis, assessment and implications. World J Gastroenterol. 2016 Jan; 22(3):1067-77.

6 Steyers CM 3rd, Miller FJ Jr. Endothelial dysfunction in chronic inflammatory diseases. Int J Mol Sci. 2014 Jun;15(7):1132449.
7 Charpentier C, Salleron J, Savoye G, Fumery M, Merle V, Laberenne JE, et al. Natural history of elderly-onset inflammatory bowel disease: a population-based cohort study. Gut. 2014 Mar;63(3):423-32.

8 Niess JH, Kaymak T, Hruz P. [The Role of the Exposome in the Emergence of Chronic Inflammatory Bowel Diseases]. Ther Umsch. 2019 Jan;75(5):261-70.

9 Rogler G, Vavricka S. Exposome in IBD: recent insights in environmental factors that influence the onset and course of IBD. Inflamm Bowel Dis. 2015 Feb;21(2):400-8.

10 Maaser C, Langholz E, Gordon H, Burisch J, Ellul P, Ramirez VH, et al. European Crohn's and Colitis Organisation Topical Review on Environmental Factors in IBD. J Crohn's Colitis. 2017 Aug;11(8 suppl_1):905-20.

11 Gevers D, Kugathasan S, Denson LA, Vázquez-Baeza Y, Van Treuren W, Ren B, et al. The treatment-naive microbiome in newonset Crohn's disease. Cell Host Microbe. 2014 Mar;15(3):382-92.

12 Yilmaz B, Juillerat $P$, Øyås O, Ramon C, Bravo FD, Franc Y, et al.; Swiss IBD Cohort Investigators. Microbial network disturbances in relapsing refractory Crohn's disease. Nat Med. 2019 Feb;25(2):323-36.

13 Claesson MJ, Cusack S, O'Sullivan O, Greene-Diniz R, de Weerd H, Flannery E, et al. Composition, variability, and temporal stability of the intestinal microbiota of the elderly. Proc Natl Acad Sci USA. 2011 Mar; 108 Suppl 1:4586-91.

14 Claesson MJ, Jeffery IB, Conde S, Power SE, O'Connor EM, Cusack S, et al. Gut microbiota composition correlates with diet and health in the elderly. Nature. 2012 Aug; 488(7410):178-84.

15 Hviid A, Svanström H, Frisch M. Antibiotic use and inflammatory bowel diseases in childhood. Gut. 2011 Jan;60(1):49-54.

16 Shaw SY, Blanchard JF, Bernstein CN. Association between the use of antibiotics and new diagnoses of Crohn's disease and ulcerative colitis. Am J Gastroenterol. 2011 Dec; 106(12):2133-42.

17 Basso PJ, Câmara NO, Sales-Campos H. Microbial-Based Therapies in the Treatment of Inflammatory Bowel Disease - An Overview of Human Studies. Front Pharmacol. 2019 Jan;9:1571. 
18 Moayyedi P, Surette MG, Kim PT, Libertucci J, Wolfe M, Onischi C, et al. Fecal Microbiota Transplantation Induces Remission in Patients With Active Ulcerative Colitis in a Randomized Controlled Trial. Gastroenterology. 2015 Jul;149(1):102-9.e6.

19 Paramsothy S, Kamm MA, Kaakoush NO, Walsh AJ, van den Bogaerde J, Samuel D, et al. Multidonor intensive faecal microbiota transplantation for active ulcerative colitis: a randomised placebo-controlled trial. Lancet. 2017 Mar;389(10075):1218-28.

20 Paramsothy S, Paramsothy R, Rubin DT, Kamm MA, Kaakoush NO, Mitchell HM, et al. Faecal Microbiota Transplantation for Inflammatory Bowel Disease: A Systematic Review and Meta-analysis. J Crohn's Colitis. 2017 Oct;11(10):1180-99.

21 Robertson DJ, Grimm IS. Inflammatory bowel disease in the elderly. Gastroenterol Clin North Am. 2001 Jun;30(2):409-26.

22 Russel MG, Stockbrügger RW. Epidemiology of inflammatory bowel disease: an update. Scand J Gastroenterol. 1996 May;31(5): 417-27.

23 Molodecky NA, Soon IS, Rabi DM, Ghali WA, Ferris M, Chernoff G, et al. Increasing incidence and prevalence of the inflammatory bowel diseases with time, based on systematic review. Gastroenterology. 2012 Jan; 142(1):46-54.e42.

24 Jeuring SF, van den Heuvel TR, Zeegers MP, Hameeteman WH, Romberg-Camps MJ, Oostenbrug LE, et al. Epidemiology and Long-term Outcome of Inflammatory Bowel Disease Diagnosed at Elderly Age-An Increasing Distinct Entity? Inflamm Bowel Dis. 2016 Jun;22(6):1425-34.

25 Lakatos PL, David G, Pandur T, Erdelyi $\mathrm{Z}$, Mester G, Balogh M, et al. IBD in the elderly population: results from a population-based study in Western Hungary, 1977-2008. J Crohn's Colitis. 2011 Feb; 5(1):5-13.

26 Everhov AH, Halfvarson J, Myrelid P, Sachs MC, Nordenvall C, Soderling J, et al. Incidence and Treatment of Patients Diagnosed With Inflammatory Bowel Diseases at 60 Years or Older in Sweden. Gastroenterology. 2018 Feb;154(3):518-28.e15.

27 Katz S, Pardi DS. Inflammatory bowel disease of the elderly: frequently asked questions (FAQs). Am J Gastroenterol. 2011 Nov;106(11):1889-97.

28 Ananthakrishnan AN, Shi HY, Tang W, Law CC, Sung JJ, Chan FK, et al. Systematic Review and Meta-analysis: Phenotype and Clinical Outcomes of Older-onset Inflammatory Bowel Disease. J Crohn's Colitis. 2016 Oct;10(10):1224-36

29 Pardi DS, Loftus EV Jr, Camilleri M. Treatment of inflammatory bowel disease in the elderly: an update. Drugs Aging. 2002;19(5): 355-63.

30 Godat S, Fournier N, Safroneeva E, Juillerat P, Nydegger A, Straumann A, et al.; Swiss IBD Cohort Study Group. Frequency and type of drug-related side effects necessitating treatment discontinuation in the Swiss Inflammatory Bowel Disease Cohort. Eur J Gastroenterol Hepatol. 2018 Jun;30(6):61220.

31 Arnott I, Rogler G, Halfvarson J. The Management of Inflammatory Bowel Disease in Elderly: Current Evidence and Future Perspectives. Inflamm Intest Dis. 2018 Jul;2(4): 189-99.

32 Butter M, Weiler S, Biedermann L, Scharl M, Rogler G, Bischoff-Ferrari HA, et al. Clinical manifestations, pathophysiology, treatment and outcome of inflammatory bowel diseases in older people. Maturitas. 2018 Apr;110: 71-8.

33 Akobeng AK, Zhang D, Gordon M, MacDonald JK. Oral 5-aminosalicylic acid for maintenance of medically-induced remission in Crohn's disease. Cochrane Database Syst Rev. 2016 Sep;9:CD003715.

34 Bokemeyer B, Hommes D, Gill I, Broberg P, Dignass A. Mesalazine in left-sided ulcerative colitis: efficacy analyses from the PODIUM trial on maintenance of remission and mucosal healing. J Crohn's Colitis. 2012 May;6(4):476-82.

35 John ES, Katz K, Saxena M, Chokhavatia S, Katz S. Management of Inflammatory Bowel Disease in the Elderly. Curr Treat Options Gastroenterol. 2016 Sep; 14(3): 285-304.

36 Lichtenstein GR, Feagan BG, Cohen RD, Salzberg BA, Diamond RH, Langholff W, et al. Drug therapies and the risk of malignancy in Crohn's disease: results from the TREAT $^{\mathrm{TM}}$ Registry. Am J Gastroenterol. 2014 Feb;109(2):212-23.

$37 \mathrm{Ha} \mathrm{CY,} \mathrm{Katz} \mathrm{S.} \mathrm{Clinical} \mathrm{outcomes} \mathrm{and} \mathrm{man-}$ agement of inflammatory bowel disease in the older patient. Curr Gastroenterol Rep. 2013 Feb; 15(2):310.

38 Kornbluth A, Sachar DB; Practice Parameters Committee of the American College of Gastroenterology. Ulcerative colitis practice guidelines in adults: American College Of Gastroenterology, Practice Parameters Committee. Am J Gastroenterol. 2010 Mar; 105(3):501-23.

39 Shah BJ, Chokhavatia S, Rose S. Fecal incontinence in the elderly: FAQ. Am J Gastroenterol. 2012 Nov;107(11):1635-46.

40 Taleban S. Challenges in the Diagnosis and Management of Inflammatory Bowel Disease in the Elderly. Curr Treat Options Gastroenterol. 2015 Sep;13(3):275-86.

41 Fangbin Z, Xiang G, Minhu C, Liang D, Feng X, Min H, et al. Should thiopurine methyltransferase genotypes and phenotypes be measured before thiopurine therapy in patients with inflammatory bowel disease? Ther Drug Monit. 2012 Dec;34(6): 695-701.

42 Lowry PW, Franklin CL, Weaver AL, Szumlanski CL, Mays DC, Loftus EV, et al. Leucopenia resulting from a drug interaction between azathioprine or 6-mer- captopurine and mesalamine, sulphasalazine, or balsalazide. Gut. 2001 Nov;49(5): 656-64.

43 Nguyen GC, Sheng L, Benchimol EI. Health Care utilization in elderly onset inflammatory bowel disease: a population-based study. Inflamm Bowel Dis. 2015 Apr;21(4) $777-82$.

44 Stepaniuk P, Bernstein CN, Nugent Z, Singh $\mathrm{H}$. Characterization of inflammatory bowel disease in elderly hospitalized patients in a large central Canadian Health region. Can J Gastroenterol Hepatol. 2015 Jun-Jul;29(5): 274-8.

45 Fardet L, Fève B. Systemic glucocorticoid therapy: a review of its metabolic and cardiovascular adverse events. Drugs. 2014 Oct; 74(15):1731-45.

46 Cerullo MA. Expect psychiatric side effects from corticosteroid use in the elderly. Geriatrics. 2008 Jan;63(1):15-8.

47 Schüle S, Rossel JB, Frey D, Biedermann L, Scharl M, Zeitz J, et al.; Swiss IBD cohor study. Prediction of low bone mineral density in patients with inflammatory bowel diseases. United European Gastroenterol J. 2016 Oct;4(5):669-76.

48 Ruiz B, Aguirre U, Estany-Gestal A, Rodella L, Ruiz P, Figueiras A, et al. Only full adherence to proton pump inhibitors protects against drug-induced upper gastrointestinal bleeding. Eur J Clin Pharmacol. 2018 Nov; 74(11):1503-11.

49 D'Haens G, Verstraete A, Cheyns K, Aerden I, Bouillon R, Rutgeerts P. Bone turnover during short-term therapy with methylprednisolone or budesonide in Crohn's disease. Aliment Pharmacol Ther. 1998 May;12(5): 419-24.

50 Rutgeerts P, Löfberg R, Malchow H, Lamers C, Olaison G, Jewell D, et al. A comparison of budesonide with prednisolone for active Crohn's disease. N Engl J Med. 1994 Sep; 331(13):842-5

51 Travis SP, Danese S, Kupcinskas L, Alexeeva O, D'Haens G, Gibson PR, et al. Once-daily budesonide MMX in active, mild-to-moderate ulcerative colitis: results from the randomised CORE II study. Gut. 2014 Mar; 63(3):433-41.

52 Lichtenstein GR, Hanauer SB, Sandborn WJ; Practice Parameters Committee of American College of Gastroenterology. Management of Crohn's disease in adults. Am J Gastroenterol. 2009 Feb;104(2):46583

53 Chaparro M, Ordás I, Cabré E, Garcia-Sanchez V, Bastida G, Peñalva M, et al. Safety of thiopurine therapy in inflammatory bowel disease: long-term follow-up study of 3931 patients. Inflamm Bowel Dis. 2013 Jun; 19(7):1404-10.

54 Sturm A, Maaser C, Mendall M, Karagiannis D, Karatzas P, Ipenburg N, et al. European Crohn's and Colitis Organisation Topical Review on IBD in the Elderly. J Crohns Colitis. 2017 Mar;11(3):263-73. 
55 Mottet C, Schoepfer AM, Juillerat P, Cosnes J, Froehlich F, Kessler-Brondolo V, et al. Experts Opinion on the Practical Use of Azathioprine and 6-Mercaptopurine in Inflammatory Bowel Disease. Inflamm Bowel Dis. 2016 Nov;22(11):2733-47.

56 Lemaitre M, Kirchgesner J, Rudnichi A, Carrat F, Zureik M, Carbonnel F, et al. Association Between Use of Thiopurines or Tumor Necrosis Factor Antagonists Alone or in Combination and Risk of Lymphoma in Patients With Inflammatory Bowel Disease. JAMA. 2017 Nov;318(17): 1679-86.

57 Beaugerie L, Brousse N, Bouvier AM, Colombel JF, Lémann $\mathrm{M}$, Cosnes J, et al.; CESAME Study Group. Lymphoproliferative disorders in patients receiving thiopurines for inflammatory bowel disease: a prospective observational cohort study. Lancet. 2009 Nov;374(9701):161725.

58 Kotlyar DS, Lewis JD, Beaugerie L, Tierney A, Brensinger CM, Gisbert JP, et al. Risk of lymphoma in patients with inflammatory bowel disease treated with azathioprine and 6-mercaptopurine: a meta-analysis. Clin Gastroenterol Hepatol. 2015 May; 13(5): 847-58.e4.

59 Bourrier A, Carrat F, Colombel JF, Bouvier AM, Abitbol V, Marteau P, et al.; CESAME study group. Excess risk of urinary tract cancers in patients receiving thiopurines for inflammatory bowel disease: a prospective observational cohort study. $\mathrm{Al}-$ iment Pharmacol Ther. 2016 Jan;43(2): 252-61.

60 Setshedi M, Epstein D, Winter TA, Myer L, Watermeyer G, Hift R. Use of thiopurines in the treatment of inflammatory bowel disease is associated with an increased risk of nonmelanoma skin cancer in an at-risk population: a cohort study. J Gastroenterol Hepatol. 2012 Feb;27(2):385-9.

61 Hagen JW, Pugliano-Mauro MA. Nonmelanoma Skin Cancer Risk in Patients With Inflammatory Bowel Disease Undergoing Thiopurine Therapy: A Systematic Review of the Literature. Dermatol Surg. 2018 Apr; 44(4):469-80.

62 González-Lama Y, Taxonera C, López-Sanromán A, Pérez-Calle JL, Bermejo F, Pajares R, et al.; Madrid Group for Study of Inflammatory Bowel Diseases (ENICMAD). Methotrexate in inflammatory bowel disease: a multicenter retrospective study focused on long-term efficacy and safety. The Madrid experience. Eur J Gastroenterol Hepatol. 2012 Sep;24(9):1086-91.

63 Köller MD, Aletaha D, Funovits J, Pangan A, Baker D, Smolen JS. Response of elderly patients with rheumatoid arthritis to methotrexate or TNF inhibitors compared with younger patients. Rheumatology (Oxford). 2009 Dec;48(12):1575-80.

64 Din S, Dahele A, Fennel J, Aitken S, Shand AG, Arnott ID, et al. Use of methotrexate in refractory Crohn's disease: the Edinburgh experience. Inflamm Bowel Dis. 2008 Jun; 14(6):756-62.

65 Huang Z, Chao K, Li M, Zhi M, Tang J, Hu $\mathrm{P}$, et al. Methotrexate for Refractory Crohn's Disease Compared with Thiopurines: A Retrospective Non-head-to-head Controlled Study. Inflamm Bowel Dis. 2017 Mar;23(3): 440-7.

66 Colman RJ, Rubin DT. Optimal doses of methotrexate combined with anti-TNF therapy to maintain clinical remission in inflammatory bowel disease. J Crohn's Colitis. 2015 Apr;9(4):312-7.

67 Herfarth H, Barnes EL, Valentine JF, Hanson J, Higgins PDR, Isaacs KL, et al. Methotrexate Is Not Superior to Placebo in Maintaining Steroid-Free Response or Remission in Ulcerative Colitis. Gastroenterology. 2018 Oct;155(4):1098-108.e9.

68 Oren R, Arber N, Odes S, Moshkowitz M, Keter D, Pomeranz I, et al. Methotrexate in chronic active ulcerative colitis: a doubleblind, randomized, Israeli multicenter trial. Gastroenterology. 1996 May;110(5):141621.

69 Seinen ML, Ponsioen CY, de Boer NK, Oldenburg B, Bouma G, Mulder CJ, et al. Sustained clinical benefit and tolerability of methotrexate monotherapy after thiopurine therapy in patients with Crohn's disease. Clin Gastroenterol Hepatol. 2013 Jun;11(6): 667-72.

70 Kornbluth A, Present DH, Lichtiger S, Hanauer S. Cyclosporin for severe ulcerative colitis: a user's guide. Am J Gastroenterol. 1997 Sep;92(9):1424-8.

71 Lobatón T, Ferrante M, Rutgeerts P, Ballet V, Van Assche G, Vermeire S. Efficacy and safety of anti-TNF therapy in elderly patients with inflammatory bowel disease. Aliment Pharmacol Ther. 2015 Aug;42(4): 441-51.

72 Weber NK, Bruining DH, Loftus EV Jr, Tremaine WJ, Augustin JJ, Becker BD, et al. Comparative outcomes of younger and older hospitalized patients with inflammatory bowel disease treated with corticosteroids. Inflamm Bowel Dis. 2013 Nov; 19(12):264451

73 Cottone M, Kohn A, Daperno M, Armuzzi A, Guidi L, D'Inca R, et al. Advanced age is an independent risk factor for severe infections and mortality in patients given antitumor necrosis factor therapy for inflammatory bowel disease. Clin Gastroenterol Hepatol. 2011 Jan;9(1):30-5.

74 Desai A, Zator ZA, de Silva P, Nguyen DD, Korzenik J, Yajnik V, et al. Older age is associated with higher rate of discontinuation of anti-TNF therapy in patients with inflammatory bowel disease. Inflamm Bowel Dis. 2013 Feb;19(2):309-15.

75 Shivaji UN, Sharratt CL, Thomas T, Smith SC, Iacucci M, Moran GW, et al. Review article: managing the adverse events caused by anti-TNF therapy in inflammatory bowel disease. Aliment Pharmacol Ther. 2019 Mar; 49(6):664-80.

76 Pallavicini FB, Caporali R, Sarzi-Puttini P, Atzeni F, Bazzani C, Gorla R, et al. Tumour necrosis factor antagonist therapy and cancer development: analysis of the LORHEN registry. Autoimmun Rev. 2010 Jan;9(3): $175-80$.

77 Strangfeld A, Hierse F, Rau R, Burmester GR, Krummel-Lorenz B, Demary W, et al. Risk of incident or recurrent malignancies among patients with rheumatoid arthritis exposed to biologic therapy in the German biologics register RABBIT. Arthritis Res Ther. 2010;12(1):R5.

78 Herrinton LJ, Liu L, Weng X, Lewis JD, Hutfless S, Allison JE. Role of thiopurine and anti-TNF therapy in lymphoma in inflammatory bowel disease. Am J Gastroenterol. 2011 Dec;106(12):2146-53

79 Siegel CA, Marden SM, Persing SM, Larson RJ, Sands BE. Risk of lymphoma associated with combination anti-tumor necrosis factor and immunomodulator therapy for the treatment of Crohn's disease: a meta-analysis. Clin Gastroenterol Hepatol. 2009 Aug; 7(8):874-81.

80 Bernstein CN, Blanchard JF, Kliewer E, Wajda A. Cancer risk in patients with inflammatory bowel disease: a population-based study. Cancer. 2001 Feb;91(4):854-62

81 Kopylov U, Vutcovici M, Kezouh A, Seidman E, Bitton A, Afif W. Risk of Lymphoma Colorectal and Skin Cancer in Patients with IBD Treated with Immunomodulators and Biologics: A Quebec Claims Database Study. Inflamm Bowel Dis. 2015 Aug;21(8):184753.

82 Long MD, Martin CF, Pipkin CA, Herfarth HH, Sandler RS, Kappelman MD. Risk of melanoma and nonmelanoma skin cancer among patients with inflammatory bowel disease. Gastroenterology. 2012 Aug;143(2): 390-9.e1.

83 Chen Y, Friedman M, Liu G, Deodhar A, Chu CQ. Do tumor necrosis factor inhibitors increase cancer risk in patients with chronic immune-mediated inflammatory disorders? Cytokine. 2018 Jan;101:7888

84 Dixon WG, Watson KD, Lunt M, Mercer LK, Hyrich KL, Symmons DP; British Society For Rheumatology Biologics Register Control Centre Consortium; British Society for Rheumatology Biologics Register. Influence of anti-tumor necrosis factor therapy on cancer incidence in patients with rheumatoid arthritis who have had a prior malignancy: results from the British Society for Rheumatology Biologics Register. Arthritis Care Res (Hoboken). 2010 Jun;62(6):75563.

85 Pache I, Rogler G, Felley C. TNF-alpha blockers in inflammatory bowel diseases: practical consensus recommendations and a user's guide. Swiss Med Wkly. 2009 May; 139(19-20):278-87. 
86 Feagan BG, Rutgeerts P, Sands BE, Hanauer S, Colombel JF, Sandborn WJ, et al.; GEMINI 1 Study Group. Vedolizumab as induction and maintenance therapy for ulcerative colitis. N Engl J Med. 2013 Aug;369(8):699710.

87 Sandborn WJ, Feagan BG, Rutgeerts P, Hanauer S, Colombel JF, Sands BE, et al.; GEMINI 2 Study Group. Vedolizumab as induction and maintenance therapy for Crohn's disease. N Engl J Med. 2013 Aug; 369(8):711-21.

88 Navaneethan U, Edminister T, Zhu X, Kommaraju K, Glover S. Vedolizumab Is Safe and Effective in Elderly Patients with Inflammatory Bowel Disease. Inflamm Bowel Dis. 2017 Apr;23(4):E17.

89 Colombel JF, Sands BE, Rutgeerts P, Sandborn W, Danese S, D'Haens G, et al. The safety of vedolizumab for ulcerative colitis and Crohn's disease. Gut. 2017 May;66(5): 839-51.

90 Feagan BG, Sandborn WJ, Gasink C, Jacobstein D, Lang Y, Friedman JR, et al.; UNITIIM-UNITI Study Group. Ustekinumab as Induction and Maintenance Therapy for Crohn's Disease. N Engl J Med. 2016 Nov; 375(20):1946-60.

91 Sandborn WJ, Su C, Sands BE, D'Haens GR, Vermeire S, Schreiber S, et al.; OCTAVE Induction 1, OCTAVE Induction 2, and OCTAVE Sustain Investigators. Tofacitinib as Induction and Maintenance Therapy for Ulcerative Colitis. N Engl J Med. 2017 May; 376(18):1723-36.

92 Sandborn WJ, Panes J, D'Haens GR, Sands BE, Su C, Moscariello M, et al. Safety of Tofacitinib for Treatment of Ulcerative Colitis, Based on 4.4 Years of Data From Global Clinical Trials. Clin Gastroenterol Hepatol. 2019 Jul; 17(8): 1541-50.

93 Winthrop KL, Curtis JR, Lindsey S, Tanaka Y, Yamaoka K, Valdez H, et al. Herpes Zoster and Tofacitinib: Clinical Outcomes and the Risk of Concomitant Therapy. Arthritis Rheumatol. 2017 Oct;69(10): 1960-8.

94 Cunningham AL, Lal H, Kovac M, Chlibek R, Hwang SJ, Díez-Domingo J, et al.; ZOE70 Study Group. Efficacy of the Herpes Zoster Subunit Vaccine in Adults 70 Years of Age or Older. N Engl J Med. 2016 Sep; 375(11):1019-32.

95 Kovac M, Lal H, Cunningham AL, Levin MJ, Johnson RW, Campora L, et al.; ZOE-50/70 Study Group. Complications of herpes zoster in immunocompetent older adults: incidence in vaccine and placebo groups in two large phase 3 trials. Vaccine. 2018 Mar; 36(12):1537-41.

96 Ananthakrishnan AN, Issa M, Beaulieu DB, Skaros S, Knox JF, Lemke K, et al. History of medical hospitalization predicts future need for colectomy in patients with ulcerative colitis. Inflamm Bowel Dis. 2009 Feb;15(2): 176-81.
97 Ha CY, Newberry RD, Stone CD, Ciorba MA. Patients with late-adult-onset ulcerative colitis have better outcomes than those with early onset disease. Clin Gastroenterol Hepatol. 2010 Aug;8(8):682-7.e1.

98 Longo WE, Virgo KS, Bahadursingh AN, Johnson FE. Patterns of disease and surgical treatment among United States veterans more than 50 years of age with ulcerative colitis. Am J Surg. 2003 Nov; 186(5):514-8.

99 Triantafillidis JK, Emmanouilidis A, Pomonis E, Cheracakis P, Hereti I, Merikas E, et al. Ulcerative colitis in the elderly: clinical patterns and outcome in 51 Greek patients. J Gastroenterol. 2001 May;36(5):312-6.

100 Polito JM 2nd, Childs B, Mellits ED, Tokayer AZ, Harris ML, Bayless TM. Crohn's disease: influence of age at diagnosis on site and clinical type of disease. Gastroenterology. 1996 Sep;111(3):580-6.

101 Tremaine WJ, Timmons LJ, Loftus EV Jr, Pardi DS, Sandborn WJ, Harmsen WS, et al. Age at onset of inflammatory bowel disease and the risk of surgery for non-neoplastic bowel disease. Aliment Pharmacol Ther. 2007 Jun;25(12):1435-41.

102 Navaneethan U, Parasa S, Venkatesh PG, Trikudanathan G, Shen B. Prevalence and risk factors for colonic perforation during colonoscopy in hospitalized inflammatory bowel disease patients. J Crohn's Colitis. 2011 Jun;5(3):189-95.

103 Chapman JR, Larson DW, Wolff BG, Dozois EJ, Cima RR, Pemberton JH, et al. Ileal pouch-anal anastomosis: does age at the time of surgery affect outcome? Arch Surg. 2005 Jun;140(6):534-9.

104 Delaney CP, Fazio VW, Remzi FH, Hammel J, Church JM, Hull TL, et al. Prospective, age-related analysis of surgical results, functional outcome, and quality of life after ileal pouch-anal anastomosis. Ann Surg. 2003 Aug;238(2):221-8.

105 Ananthakrishnan AN, McGinley EL, Binion DG. Inflammatory bowel disease in the elderly is associated with worse outcomes: a national study of hospitalizations. Inflamm Bowel Dis. 2009 Feb;15(2):182-9.

106 Turrentine FE, Wang H, Simpson VB, Jones RS. Surgical risk factors, morbidity, and mortality in elderly patients. J Am Coll Surg. 2006 Dec;203(6):865-77.

107 Almogy G, Sachar DB, Bodian CA, Greenstein AJ. Surgery for ulcerative colitis in elderly persons: changes in indications for surgery and outcome over time. Arch Surg. 2001 Dec;136(12):1396-400.

108 Page MJ, Poritz LS, Kunselman SJ, Koltun WA. Factors affecting surgical risk in elderly patients with inflammatory bowel disease. J Gastrointest Surg. 2002 Jul-Aug;6(4): 606-13.

109 Halmos EP, Gibson PR. Dietary management of IBD_insights and advice. Nat Rev Gastroenterol Hepatol. 2015 Mar; 12(3): 133-46.
110 Massironi S, Rossi RE, Cavalcoli FA, Della Valle S, Fraquelli M, Conte D. Nutritional deficiencies in inflammatory bowel disease: therapeutic approaches. Clin Nutr. 2013 Dec;32(6):904-10.

111 Mijac DD, Janković GL, Jorga J, Krstić MN. Nutritional status in patients with active inflammatory bowel disease: prevalence of malnutrition and methods for routine nutritional assessment. Eur J Intern Med. 2010 Aug;21(4):315-9.

112 Long MD, Martin C, Sandler RS, Kappelman MD. Increased risk of pneumonia among patients with inflammatory bowel disease. Am J Gastroenterol. 2013 Feb; 108(2):240-8.

113 Long MD, Martin C, Sandler RS, Kappelman MD. Increased risk of herpes zoster among 108604 patients with inflammatory bowel disease. Aliment Pharmacol Ther. 2013 Feb; 37(4):420-9.

114 Tinsley A, Navabi S, Williams ED, Liu G, Kong L, Coates MD, et al. Increased Risk of Influenza and Influenza-Related Complications Among 140,480 Patients With Inflammatory Bowel Disease. Inflamm Bowel Dis. 2019 Jan;25(2):369-76.

115 Toruner M, Loftus EV Jr, Harmsen WS, Zinsmeister AR, Orenstein R, Sandborn WJ, et al. Risk factors for opportunistic infections in patients with inflammatory bowel disease. Gastroenterology. 2008 Apr; 134(4):929-36.

116 Click B, Regueiro M. Managing Risks with Biologics. Curr Gastroenterol Rep. 2019 Jan; 21(2):1.

117 Farraye FA, Melmed GY, Lichtenstein GR, Kane SV. ACG Clinical Guideline: Preventive Care in Inflammatory Bowel Disease. Am J Gastroenterol. 2017 Feb;112(2):24158.

118 Moscandrew M, Mahadevan U, Kane S. General health maintenance in IBD. Inflamm Bowel Dis. 2009 Sep;15(9):1399409.

119 Rubin LG, Levin MJ, Ljungman P, Davies EG, Avery R, Tomblyn M, et al.; Infectious Diseases Society of America. 2013 IDSA clinical practice guideline for vaccination of the immunocompromised host. Clin Infect Dis. 2014 Feb;58(3):309-18.

120 Papa A, Gerardi V, Marzo M, Felice C, Rapaccini GL, Gasbarrini A. Venous thromboembolism in patients with inflammatory bowel disease: focus on prevention and treatment. World J Gastroenterol. 2014 Mar; 20(12):3173-9.

121 Kandiel A, Fraser AG, Korelitz BI, Brensinger C, Lewis JD. Increased risk of lymphoma among inflammatory bowel disease patients treated with azathioprine and 6-mercaptopurine. Gut. 2005 Aug;54(8):1121-5.

122 Hemmens VJ, Moore DE. Photochemical sensitization by azathioprine and its metabolites-II. Azathioprine and nitroimidazole metabolites. Photochem Photobiol. 1986 Mar;43(3):257-62. 
123 O’Donovan P, Perrett CM, Zhang X, Montaner B, Xu YZ, Harwood CA, et al. Azathioprine and UVA light generate mutagenic oxidative DNA damage. Science. 2005 Sep; 309(5742):1871-4.

124 Beigel F, Steinborn A, Schnitzler F, Tillack C, Breiteneicher S, John JM, et al. Risk of malignancies in patients with inflammatory bowel disease treated with thiopurines or anti-TNF alpha antibodies. Pharmacoepidemiol Drug Saf. 2014 Jul;23(7):735-44.

125 Rungoe C, Simonsen J, Riis L, Frisch M, Langholz E, Jess T. Inflammatory bowel disease and cervical neoplasia: a population- based nationwide cohort study. Clin Gastroenterol Hepatol. 2015 Apr;13(4):693-700. e1

126 Pandey N, Herrera HH, Johnson CM, MacCarthy AA, Copeland LA. Preventative care for patients with inflammatory bowel disease in the Veterans Health Administration. Medicine(Baltimore).2016Jul;95(27):e4012.

127 Annese V, Daperno M, Rutter MD, Amiot A, Bossuyt P, East J, et al.; European Crohn's and Colitis Organisation. European evidence based consensus for endoscopy in inflammatory bowel disease. J Crohn's Colitis. 2013 Dec;7(12):982-1018.
128 Baars JE, Kuipers EJ, van Haastert M, Nicolaï JJ, Poen AC, van der Woude CJ. Age at diagnosis of inflammatory bowel disease influences early development of colorectal cancer in inflammatory bowel disease patients: a nationwide, long-term survey. J Gastroenterol. 2012 Dec;47(12): 1308-22.

129 Shi HY, Chan FK, Leung WK, Li MK, Leung CM, Sze SF, et al. Natural History of Elderlyonset Ulcerative Colitis: Results from a Territory-wide Inflammatory Bowel Disease Registry. J Crohn's Colitis. 2016 Feb;10(2): 176-85. 